\title{
Idiosyncratic exceptions to the probability-matching decision-rule in visual discrimination
}

\author{
THEODORE PARKS ${ }^{1}$ AND THOMAS NATSOULAS \\ UNIVERSITY OF CALIFORNIA, DA VIS
}

\begin{abstract}
Human "Yes-No" signal-detection performance was tested under a modified perceptual-defense procedure. A majority of $S s$ tended to match the relative frequency with which they gave affirmative responses to the relative frequency at which signals were presented. These Ss thereby replicated the "probability-matching" behavior found in previous signaldetection and discrimination studies. However, in marked contrast to those previous results, another large set of Ss showed a tendency toward preponderant use of one of the two responses (typically, of "No") rather than toward probabilitymatching. The evidence failed to suggest that the latter effect was related to a lesser ability to make the requisite sensory discrimination or to response inhibition induced by taboo stimuli.
\end{abstract}

Several recent studies have shown that human Ss who are required to perform a two-choice signal-detection or discrimination task tend to adjust the relative frequencies with which they emit each of the two response alternatives to match the relative frequencies of the two stimulus events (Atkinson, Carterette, \& Kinchla, 1964; Kinchla \& Atkinson, 1964; Kinchla, 1966; Parks \& Kellicutt, 1968; Creelman \& Donaldson, 1968). This phenomenon has been found to occur even if accuracy of performance is low but only if Ss are adequately informed of the latter values or receive trial-by-trial feedback (Kinchla, 1966; Tanner, Haller, \& Atkinson, 1967; Parks \& Kellicutt, 1968). The present study revealed one further severe limitation on the generality of this effect.

\section{METHOD}

The Ss were 124 college underclassmen volunteers $(70$ females and 54 males).

Stimuli were presented on a three-channel tachistoscope (Scientific Prototype, Model GA 320) arranged such that each trial consisted of (a) the presentation of a "cue word" for $.3 \mathrm{sec}$ (with an incident illumination of $.6 \mathrm{ft}-\mathrm{c}$, (b) the presentation of a blank white surface for $1.0 \sec (2.2 \mathrm{ft}-\mathrm{c})$, and (c) a brief presentation (see below) of a test stimulus (.4 ft-c). The relatively low illumination present during Part (c) resulted in a distinctive dimming of the stimulus field. During the $15-\mathrm{sec}$ interval between trials Ss were presented with the blank surface used in the second part of the above sequence.

The cue words consisted of 10 neutral words (trade, rains, child, chair, broom, music, river, stove, shelf, apple) and 10 relatively taboo words (whore, bleed, fairy, filth, penis, vomit, raped, balls, Kotex). All were printed in $1 / 2$-in. black letters on white paper. Half of the Ss of either sex were presented with the neutral cues and half with the taboo cues, each item being presented four times for a total series of 40 trials. The order of presentation was randomly determined, but with the restriction that each word appeared once in each 10-trial block.

The test stimulus was either the set of letters, "XOXOX," printed in $1 / 2-i n$. black letters on white paper or blank white paper. After a random half of the presentations of any given cue word the XOXOX stimulus was presented, but with the restriction that five of any block of 10 trials involved a blank-screen test presentation and half involved the XOXOX stimulus. The duration of the test stimulus was either $19 \mathrm{msec}$ (11 Ss of each sex within each cue condition) or $15 \mathrm{msec}$. The test stimuli, in a prearranged sequence of XOXOX patterns and blank spaces, were printed on a roll of paper which was advanced one step after each trial, thus eliminating auditory cues that might indicate that the same test stimulus was or was not being presented again and also preventing $E$ from knowing which of the test stimuli was present on any trial.

According to the instructions given to each $S$, each trial consisted of the presentation of a word (that these might be taboo was not mentioned), followed by a pause, and then a brief dimming of illumination during which he would be presented either with the "same word" he had just seen (on half the trials) or with a blank screen (on the remaining half). His task on each trial was to decide whether the word or only the blank screen had been presented during the brief dimming. He was permitted to guess but encouraged to "be as accurate as possible." Thus, the instructions emphasized accuracy in the use of the two responses and did not direct Ss to probability match. In order to insure that he understood what was meant by the "brief dimming," each $\mathrm{S}$ was allowed a few practice trials during which the word, "Ready," was used as a cue word.

As mentioned above, the cue word never did reappear as the test stimulus. Instead, on half the trials the XOXOX was presented, this being at such a duration and intensity that only one of the 124 Ss reported seeing any letters that were not in the original word. Subsequent interviews revealed that the most information the other Ss were capable of reporting about the test stimuli was a general greyness or small bits of black on some trials. The XOXOX stimulus was used in order to control for possible effects of differences in shape or frequency of usage between the neutral and taboo stimuli. As a result, the present experiment involved the effects of exposure to and expectation of neutral and taboo stimuli on detection responses to nonsense stimuli.

\section{RESULTS AND DISCUSSION}

Discrimination performance for each condition is summarized in Table 1 . On the average $S$ s in each condition showed a small but reliable ability to discriminate a blank from the patterned stimulus. That is, across all conditions, Ss responded "Yes" to .50 of the signal trials and only .33 of the blank trials: $F(1,116)=43.33, p<.01$.

The datum of central interest for the probability-matching hypothesis, however, was the overall rate (irrespective of accuracy) at which the "Yes" response was emitted. The overall mean relative frequency of "Yes" responses that was obtained, .42 , clearly fails to support the probability-matching

Table 1

Mean Proportion of "Yes" Responses

\begin{tabular}{|c|c|c|c|c|}
\hline \multirow[b]{3}{*}{ Neutral Cue } & \multirow[b]{3}{*}{$\begin{array}{r}19 \mathrm{msec} \\
15 \mathrm{msec} \\
\text { Mean }\end{array}$} & \multicolumn{2}{|c|}{ Stimulus } & \multirow[t]{2}{*}{ All Trials } \\
\hline & & XOXOX & BLANK & \\
\hline & & $\begin{array}{l}.49 \\
.48 \\
.48\end{array}$ & $\begin{array}{r}.34 \\
.34 \\
.34\end{array}$ & $\begin{array}{l}.41 \\
.41\end{array}$ \\
\hline Taboo Cue & $\begin{array}{r}19 \mathrm{msec} \\
15 \mathrm{msec} \\
\text { Mean }\end{array}$ & $\begin{array}{l}.57 \\
.45 \\
.51\end{array}$ & $\begin{array}{l}.26 \\
.39 \\
.33\end{array}$ & $\begin{array}{l}.42 \\
.42\end{array}$ \\
\hline
\end{tabular}


Table 2

Frequency Distribution of Ss for Relative Frequency of Total "Yes" Responses on all Trials

\begin{tabular}{cccccc}
\hline Interval & $.00-.20$ & $.21-.40$ & $.41-.60$ & $.61-.80$ & $.81-1.00$ \\
\hline $\mathrm{f}$ & 21 & 24 & 69 & 9 & 1 \\
\hline
\end{tabular}

hypothesis (since signals occurred on .50 of the trials). Examination of the distribution of the relative frequencies of "Yes" responses across Ss (Table 2) revealed that extreme individual differences lay behind this failure. That is, while a majority of Ss gave "Yes" responses on more than .40 , but not more than .60 , of all trials (thus approximating probabilitymatching), several others tended to respond "No" on all or nearly all trials and one S responded "Yes" on nearly all trials. These between-S differences were reliable: chi square $=619$, $\mathrm{df}=123, \mathrm{p}<.01$.

Individual tendencies in the direction of relatively exclusive use of the "No" response apparently were not related to the accuracy of concomitant discrimination performance. For example, those Ss who emitted "Yes" responses on more than .40 , but not more than .60 , of all trials $(\mathrm{N}=69)$ made "Yes" responses to means of .58 and .42 of the signal and blank presentations, respectively. On the other hand, for those Ss who emitted "Yes" responses on more than .10 , but less than .20 , of all trials $(\mathrm{N}=6)$ the corresponding mean values were .28 and .08 . According to the two-threshold detection model of Atkinson (1963), both of these levels of discrimination performance would have been reasonably likely if a detection threshold existed such that approximately .18 of all signals exceeded that threshold. The difference between these sets of Ss was therefore not in their relative sensitivity to the stimuli but, rather, in their relative willingness to emit "Yes" responses when suprathreshold events did not occur.

If, then, major differences in response bias were present between Ss, the evidence did not suggest, in turn, that those effects were simply instances of response inhibition produced by the taboo cue. That is, of the 21 Ss who gave "Yes" responses on .20 or less of all trials $(\mathrm{N}=21), 8$ had been presented with taboo cue words while 13 had received neutral cues. Furthermore, across all Ss within each condition the mean overall frequencies of "Yes" responses were quite similar (see Table 1). Thus, if between-S differences are to be attributed to differences in the symmetry of subjective payoff matrixes, such instances of asymmetry apparently must be attributed to extra-experimental experience with the responses, "Yes" and "No."

\section{REFERENCES}

ATKINSON, R. C., CARTERETTE, E. C., \& KINCHLA, R. A. The effect of information feedback upon psychophysical judgments. Psychonomic Science, 1964, 1, 83.

CREELMAN, C. D., \& DONALDSON, W. ROC curves for discrimination of linear extent. Journal of Experimental Psychology, 1968, 77, 514516 .

KINCHLA, R. A. A comparison of sequential effects in detection and recognition. Experimental Psychology Series, Psychology Department, New York University, Technical Report No. 1, 1966.

KINCHLA, R. A., \& ATKINSON, R. C. The effect of false-information feedback upon psychophysical judgments. Psychonomic Science, $1964,1,317$.

PARKS, T. E., \& KELLICUTT, M. H. The probability-matching decision rule in the visual discrimination of order. Perception \& Psychophysics, $1968,3,356-360$

TANNER, T. A., JR., HALleR, R. W., \& ATKINSON, R. C. Signal recognition as influenced by presentation schedules. Perception \& Psychophysics, 1967, 2, 349-358.

\section{NOTE}

1. Address: Department of Psychology, University of California, Davis, California 95616.

(Accepted for publication October 14, 1968.) 